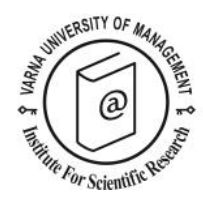

\title{
On the relationships between digital brand evidence, relationship quality and behavioural intentions among online tourism agencies' customers
}

\author{
Apostolos Giovanis ${ }^{1 *}$, Ioannis Rizomyliotis ${ }^{2}$ and Androniki Kavoura ${ }^{3}$
}

\footnotetext{
${ }^{1}$ University of West Attica, Athens, Greece, E-mail: agiovanis@uniwa.gr

${ }^{2}$ University of West Attica, Athens, Greece

3 University of West Attica, Athens, Greece

${ }^{*}$ Corresponding author
}

\begin{abstract}
This paper aims to propose and empirically validate a measure of brand evidence of Online Travel Agencies (OTA), representing all relevant brand associations that customers are doing when evaluating an online brand, and then investigate its effect in building strong consumer-brand relationships and creating favourable consumer behavioural intentions. To check the validity of the proposed model, a survey of 971 users of OTA platforms in Greece was conducted and data was analysed with PLS. Results fully support the validity of the proposed brand evidence index, as several OTA's brand related associations that a customer develops, before and during service encounters, shape the index expressing brand evidence. Furthermore, the findings confirmed the significant effects of brand evidence on both brand relationships quality and consumer behavioural intentions towards the brand. The current research effort significantly contributes to the field of digital booking services, as it appears to be the first to measure digital brand evidence and investigate their role to strengthen consumer-brand relationships.
\end{abstract}

Key words: Digital branding; brand evidence; brand relationship quality; behavioural intentions; online travel agencies; tourism marketing

Citation: Giovanis, A., Rizomyliotis, I. and Kavoura, A. (2022). On the relationships between digital brand evidence, relationship quality and behavioural intentions among online tourism agencies' customers. European Journal of Tourism Research 30, 3005 . 


\section{Introduction}

Along with the growth of ICTs, doing business in the internet is rapidly gaining importance in the tourism industry in general and in the context of booking services in particular (e.g., Buhalis and Law, 2008; Mouakket and Al-hawari, 2012; Navío-Marco et al., 2018). Along with the Internet, mobile telecommunication technologies have dramatically transformed the tourism industry, especially travel services distribution channels (Xiang et al., 2015).

OTA are now the preferred sales channel for customers, mostly seeking for travel and accommodation services, and as such their importance has attracted increasing attention among researchers and practitioners (Sharma et al., 2020). According to Rezgo (2019), OTA are travel aggregators who sell travel-related services to consumers via the Internet. They establish a connection between customers and offline service providers like hotel, flight, and car hire companies among others. OTA are expanding quickly worldwide (Talwar, et al., 2020). Their market share in the online travel booking market is about forty percent and they have become a significant threat for other companies' viability (Martin-Fuentes and Mellinas, 2018). Despite the successful implementation of their web-based services, OTA are now shifting their business model to mobile apps in order to better serve their customers though their smartphones (Talwar, et al., 2020). Moreover, the adoption of new technologies and practices, such as consumer intelligence, data mining, and artificial intelligence, accelerate OTA's business transformation and changes the tourism industry's future (Buhalis and Sinarta, 2019).

Despite the fact that online booking services' usage expands worldwide, it's time for OTA to pay attention not only on how to acquire more customers, but on the improvement of their customer retention rates through the establishment of appropriate marketing strategies and tactics (e.g., Bilgihan and Bujisic, 2015; Mouakket et al, 2012). This is based on the fact that competition is one-click away and consumers may be able to find a better offer without additional effort. In this highly competitive environment, OTAs investment on branding is of paramount importance towards gaining a differentiated advantage over competitors (e.g., Ozturk et al., 2016; Rowles, 2014; Rowley, 2009; Zhang et al., 2011). Sreejesh and Roy (2015) argue that branding is the most effective strategy for service providers to differentiate their services from those offered by their competitors and achieve a sustainable competitive advantage in the market. Earlier studies in the field of brand management find that consumers use the type of the of the relationships they have developed with a brand to differentiate it from other brands (Fournier, 1988). Additionally, De Chernatony and Dall'Olmo Riley (1997) and Veloutsou (2015), in the offline service setting, and Rowley (2009), in the online service setting, have theoretically discussed and empirically validated the role of brands in establishing and developing strong consumer-brand relationships and, further, appreciate that brands offer a broad range of benefits to the company apart from being used to develop its identity that differentiate it in the customer's mind. Given the positive effect of strong consumer-service brand relationships on consumers' behaviour, OTA have to find ways to strengthen the ties with their customers by consistently invest on the service brand's elements that are associated with and determine the brand relationship quality level (e.g., Bilgihan and Bujisic, 2015; Nyffenegger et al., 2014; Ozturk et al., 2016; Rowles, 2014; Tsai, 2011; Yoon and Youn, 2016; Zhang et al., 2011).

Finally, another significant issue in online service branding is the development of consumer-brand relationships based on the brand experience that a customer perceives when using the brand. Brand management theory and practice suggest that brand evidence, representing the service brand associations participating in brand evaluation (Grace and O'Cass, 2005), is used as brand relationship development's motivator which, in turn, enhances the impact of perceived brand deliverables on consumers' behavioural responses (e.g., Bilgihan and Bujisic, 2015; Nyffenegger et al., 2014; Rowley 2009; 
Sreejesh and Roy, 2015). Therefore, OTA that are able to provide a positive brand experience, they will be able to establish and sustain strong ties with their customers and achieve more favourable consumer behavioural responses (Yoon and Youn, 2016).

Although there are studies investigating the role of brand evidence in determining brand relationship quality and consumers' behavioural responses in the offline service context, to the best of authors' knowledge, there are no many empirical studies in the online service context (Rowles, 2014). Taking into account this research gap, the aim of this paper is to propose an adaptation of the brand evidence's measure used in the offline service setting to the online service setting and then to propose a model investigating the effects of online service brand evidence on the development of consumer-brand relationships and the achievement of favourable consumer's behavioural intentions in the OTA's setting. The findings of this study are expected to be beneficial for OTAs seeking to develop a brand identity that will differentiate them from its competitors in their customers' mind and create through this a sustainable competitive advantage (Bilgihan and Bujisic, 2015; Fournier, 1998; Rowles, 2014; Sreejesh and Roy, 2015).

\section{Model conceptualization and research hypotheses}

Attempting to model the effect of consumers' evaluations about certain elements associated with a service brand and consumer-brand relationship quality with their behavioural intentions in the OTAs' service context, a structural model is proposed where consumer-brand relationship quality and behavioural intentions are seen as the consequence of consumers' evaluation of various service brand dimensions (brand evidence). In the following sections, the definition of the concepts and the relationships among the model's constructs are discussed.

\section{Digital brand evidence}

A brand is defined as "a name, term, sign, symbol, or design or combination of them which is intended to identify the goods and services of one seller or group of sellers and to differentiate them from those of competitors" (Kotler and Armstrong, 2010, p. 188). De Chernatony and Dall'Olmo Riley (1997, p. 47), however, argue that brands' role is broader than being used for service providers offers' identification and differentiation and they propose that "a brand is the link between firms' marketing activities and consumers' perceptions of functional and emotional elements in their experience with the product/service and the way it is presented". Rowley (2009) defines digital branding as a value creation process though the provision of a consistent and compelling offer, combined with a positive customer experience that will allow online service providers to build strong consumer-brand relationships, which, in turn, will give them the opportunity to achieve higher customer retention rates; charge higher prices; and better manage their brand positioning.

In the offline context, Grace and O'Cass (2005) use the concept of brand evidence defined as "the set of service brand associations experienced by the consumer during the pre-purchase and consumption stages" (p. 128), to express consumers' experience with a brand. They also claim that the brand evidence is determined by five brand associations made by customers during the brand evaluation process: brand name's meaning, service quality level; perceived monetary value, positive and negative feelings and congruence between consumer's and brand's personality. In the pre-consumption stage, consumers primarily use search characteristics (i.e., brand name, servicescape and price level) to evaluate a service brand (Grace and O' Cass, 2005; Krystallis and Chrysochou, 2014; O' Cass and Grace, 2004). In the consumption stage, customers evaluate service brand attributes that were not able to evaluate previously such as service output quality, employees service, feelings and self-image congruence (Krystallis and Chrysochou, 2014). In accordance with the suggestions of Rowley (2009), this study 
proposes an adaptation of the construct, proposed by Grace and O' Cass (2005), to model brand evidence in the offline context in order to considering the differences that emerge in the online booking market.

According to Keller (1993) and Grace and O'Cass (2005), the meaning of the brand name is very important in the consumers' evaluation process as it is used by them to recall brand benefits and make product/service inferences and assessments. The brand name is the core element of the brand and is considered as service companies' asset (Keller, 1993). It is further suggested that the role of brand name is even more significant in the online digital service settings, where there is lack of information, and the brand name is used by customers to decide in not well-informed situations (e.g., Degeratu et al., 200o).

The second component of brand evidence refers to price/value for money, which express consumers' perception of what they need to sacrifice to obtain the service's benefits (Zeithaml, 1988). Several previous studies, either in the offline services context (e.g., Brady et al., 2005) or in the online services context (e.g., Kuo et al., 2009; Lin and Wang, 2006; Talwar et al. 2020; Toufaily et al., 2013), confirmed the impact of perceived value on consumers' service evaluation process.

Service quality is the third component of brand evidence and is crucial in the development of dominant service brands, because it enhances the perceived brand's value and supports better a brand's positioning (e.g., Aaker, 1996; Nam et al., 2011). Chang et al. (2019) and Huang et al. (2020) show that OTA can improve their acquisition and retention rates and reduce customers' intention to rebook using the hotel websites by increasing the quality of their website services. Earlier studies in the offline service context conceptualize service quality as a multidimensional construct reflecting service's core quality, interaction quality and servicescape quality (Brady and Cronin, 2001). The same conceptualization is also used by Grace and O' Cass (2005) to consider the role of service quality in the formation of brand evidence in the offline context. Service quality in the online context is defined as "... the extent to which a website facilitates efficient and effective shopping, purchasing, and delivery of product and services" (Parasuraman et al, 2005, p. 217). As such, when customers assess their online shopping experiences, they not only evaluate the product/service offering but their total shopping experience, including different sub-processes such as: information searching, product evaluation, purchase decision making, transaction completion, and processes related to product delivery/return and customer service. There are many different multidimensional scales aiming to measure online service quality (e.g., Barnes and Vidgen, 2002; Bauer et al., 2006; Collier and Bienstock, 2006; Cristobal et al., 2007; Loiacono et al., 2007; Parasuraman et al., 2005; Rolland and Freeman, 2010; Webb and Webb, 2004; Wolfinbarger and Gilly, 2003; Yang et al., 2005; Yoo and Donthu, 2001; Zeithaml et al., 2002). Several factors have been used by all these studies to conceptualize the way users evaluate the quality of the services provided by e-tailer's websites, but there is no an agreement on their number and nature, as they are mostly related with the service setting (Ladhari, 2010). There are, however, six factors that are consistently present in all the above e-service quality measures (Ladhari, 2010): reliability/fulfilment, which refers to the ability of online service providers to provide its services in an accurate and dependable manner; responsiveness, which refers to the ability of online service providers to be responsive to customer needs, with an emphasis on their willingness to promptly respond; privacy/security, which refers to the ability of online service provider to develop mechanisms devoted to the protection of personal and financial information and the way this info is used; information quality/benefits, which refers to the extent of which the provided information is suitable to what the customers want to do; ease of use/usability, which express the customers' required effort to find the required information and navigate into the online service provider's webpage; and web design, which refers to the graphic design, content production, and webpage layout of online service providers' webpage. Based on the above discussion the three-service 
quality-related dimensions of brand evidence (i.e. outcome quality, servicescape, and employee service) concerning conventional service settings will be replaced by the above six dimensions representing the service quality dimensions that consumers assess in online service settings.

Feelings that consumers express towards the brand are the next component shaping customers' perception of a brand and play an important role in brand's deliverables evaluation mechanism (Babin and Babin, 2001). Kuo and Feng (2013) argue that feelings and emotions of consumers about a brand, shape their experience with the brand. In services that are mostly intangible and with physical limited cues, customers' emotions towards their service providers affect service evaluations (Grace and O' Cass, 2005). Positive feelings towards a brand are considered to be a significant part of brand equity and determines customer's resonance (Keller, 1993). Sreejesh and Roy (2015) suggests that feelings affect customers' decision to augment a relationship with a brand and be loyal to it in the future.

The sixth brand association related to brand evidence is self-image congruence which refers to the similarity between customers' and service brand's personality (Sirgy et al., 1997). Previous research efforts empirically validate that the greater the congruity between the brand image and the consumer's actual or ideal self, the greater the customers' willingness to buy the brand (e.g., Nyffenegger et al., 2014; O'Cass and Lim, 2000; 2002; Sirgy et al., 1997; Sop, 2020). Self-image congruence has been found to effectively predict tourists' loyalty towards destinations (e.g., Xu and Pratt, 2018; Wassler et al., 2019) and hotels (e.g. Sop and Kozak, 2019; Wong et al., 2020). Hosany and Martin (2012) found that selfimage congruence positively affects brand experience and through this customers' satisfaction and intentions to recommend. Finally, Sirgy et al. (1997) argued that if consumers perceive that the brand image match with their self-image, then they increase brand usage and formulate a more positive attitude toward this brand.

Based on the suggestions of Grace and O' Cass (2005) about brand evidence's conceptualization, the current study suggests that brand evidence for an online service brand, such as an OTA, is perceived as a second-order formatively measured construct, made of all six aforementioned brand associations that a customer is using when evaluating a service brand. This construct will be investigated as a consumerbrand relationship building's and consumers' positive behavioural responses' driver in the service setting of OTA.

\section{Consumer- digital brand relationship quality}

Establishing, augmenting and maintaining strong consumer-brand relationships provides to service companies with a sustainable competitive advantage (e.g., Fournier, 1998; Sreejesh and Roy, 2015; Veloutsou, 2015). Based on Tsai (2011) "consumer-brand relationships refer to the psychological bonds developed between the consumer and the brand and are found to enhance brand loyalty of targeted customers" (p. 1194). Veloutsou (2015) suggest that many service providers use their brands to develop strong relationships with their customers, at least with those that showing a strong preference for them and Tsai (2011) suggests the use of relationship marketing practices to investigate the nature of the association between consumers and brands and its consequences (i.e., brand loyalty, repurchase intentions, price premium etc.)

Consumer-brand relationship quality, either in the offline or in the online context, is considered to be a multidimensional construct. Past research efforts propose that it reflects brand satisfaction, brand trust, and brand commitment (e.g., Brun et al., 2014; Papista and Dimitriadis, 2012). Satisfaction refers to customers' affective state resulting from their service encounters deliverables' evaluation during their relationship with a brand (Oliver, 1999). Trust refers to customers' confidence in the online exchange, 
or the channel that online exchange takes place (Ribbink et al., 2004). Finally, brand commitment refers to the positive feelings that customers have developed towards a brand with the expectation to retain this valued relationship with it in the future (Aaker et al., 2004; Ramírez et al., 2017). Following the suggestions of many previous studies, brand relationship quality is measured as a second-order reflectively measured construct reflecting brand satisfaction, trust and commitment (e.g., Brun et al., 2014; Giovanis and Melanthiou, 2017).

While previous studies assume that brand evidence affects only brand satisfaction, the current study claims that brand evidence represents a consumer-brand relationship building motivator given that many previous studies suggest the direct impact of all brand evidence components on consumer-brands relationship dimensions (Rowles, 2014; Rowley, 2009). In an era of e-marketplaces, brand evidence, a concept reflecting customers' online brand experience in different stages of the consumption process, is of paramount importance for OTA, given that it has been shown to exert a bigger impact on consumers' behaviour than just price offers (e.g., Bilgihan et al., 2016; Ye et al., 2020).

For example, Giovanis and Melanthiou (2017) found that service quality of web-platforms significantly enhances the level of brand relationship quality in the e-tailing context. Moreover, the studies of Giovanis and Athanasopoulou (2014); Keating et al. (2011) and Ladhari and Leclerc (2013) found that online service quality has a strong impact on brand relationship quality (either in an aggregated or a disaggregated specification) in the online services context. Many previous studies identified the significance of perceived value in building strong consumer-brand relationships. For example, earlier studies in the offline context (Chaudhuri and Holbrook, 2001; Loureiro et al., 2014) and in the online context (Bilgihan and Bujisic, 2015, Bilgihan, 2016 and Talwar et al. 2020) have empirically validated the direct effect of perceived value-for-money, part of utilitarian value, and hedonic/affective value, expressing consumers' feelings towards a brand, on brand relationship quality respectively. Nyffenegger et al. (2014) empirically confirmed that consumers develop both emotion's-based and object-relevant beliefs-based relationships with brands that they can identify with. Finally, Yoon and Youn (2016) found that brand experience in the online context have a positive effect to all three relationship quality constructs. Therefore, the following hypothesis yields:

\section{H1: Brand evidence has a positive impact on consumer-brand relationship quality}

\section{Behavioural intentions}

Consumers' behavioural intentions is used in marketing studies to express customers' willingness to develop certain categories of behaviours such as, repurchase intentions, pay price premium, referrals and complaining behaviour (Zeithaml et al., 1996). In many studies, they are associated with the conative stage of the loyalty chain including four types of loyalty (i.e. cognitive, affective, conative, and behavioural) (Oliver, 1999). In online retailing, behavioural intentions are conceptualized as a multidimensional construct, mostly having repurchase intention and word-of-mouth communications, as its dimensions (Altunel and Koçak, 2017; Zeithaml et al., 1996; Chiu et al., 2013). Repurchase intentions refers to "the individual's judgment about buying again a designated service from the same company, taking into account his or her current situation and likely circumstances" (Hellier et al., 2003, p. 1764). Word-of-mouth communication relates to "informal communications directed at other consumers about the ownership; usage, or characteristics of particular goods and services and/or their sellers" (Westbrook, 1987, p. 261). According to the suggestions of Chiu et al. (2013), behavioural intentions are measured as a second-order reflective construct that includes repurchase intentions and word-of-mouth communications as its first-order dimension. 
Additionally to the empirically validated direct effect of consumer-brand relationship quality on consumers' positive behavioural responses in the online context, such as brand loyalty, repurchase intentions and brand advocacy (e.g., Bilgihan and Bujisic, 2015; Giovanis and Melanthiou, 2017; Giovanis, 2016; Rowles, 2014; Sun, 2010; Keating et al., 2011; Toufaily et al., 2013; Zhang et al., 2011), the current study hypothesizes the impact of brand evidence on consumers behavioural intentions as well its indirect effects mediated by consumer-brand relationship quality (e.g., Altunel and Koçak, 2017; Grace and O' Cass, 2005; Krystallis and Chrysochou, 2014). Finally, in the OTA's services delivery context, Ye et al. (2020) empirically validated the impact of brand experience on brand preference and through the latter on buying intentions. Thus, the following research hypotheses are forms:

\section{H2: Brand relationship quality has a positive impact on consumers' behavioural intentions H3: Brand evidence has a positive impact on consumers' behavioural intentions}

Taking together, $\mathrm{H}_{1}, \mathrm{H}_{2}$, and $\mathrm{H}_{3}$ suggest a mediating relationship in which brand relationship quality enhances the impact of brand evidence on behavioural intentions. The empirical findings concerning this relationship are contradicting. For example, Bilgihan and Bujisic (2015) argue that utilitarian and hedonic/emotional features of online booking brands don't directly affect brand loyalty, as brand relationship quality fully mediates the relationship between these two constructs. This nomological framework among brand evidence, brand relationship quality and brand loyalty, known as the "chainof-impact", prevails in the literature. However, other research studies suggest a partial mediation effect of brand relationship quality on this relationship in the online services context (e.g., Giovanis and Melanthiou, 2017; Sun, 2010; Zhang et al., 2011). For example, Yoon and Youn (2016) found that, as online experience increases, customers' brand satisfaction (one of the three relationship quality dimension) and behavioural intentions can also be enhanced, stressing the special role of transaction-specific brand experiences in consumers' online brand evaluation and behavioural intentions. Consequently, the following hypothesis is proposed:

$\mathrm{H}_{4}$ : Brand relationship quality partially mediates the impact of brand evidence on consumers' behavioural intentions.

Based on the hypotheses developed, the modelling framework investigating the interplay between brand evidence and brand relationship quality in determining consumer's behavioural intentions towards OTA brands is depicted in Figure 1.

\section{Research Methodology}

The modelling framework under investigation was tested with data collected in Athens, the capital of Greece, during the first quarter of 2016. To collect the data, using self-administered questionnaires, a convenience sampling method was employed. One thousand five hundred questionnaires $(1,500)$ were distributed by senior university students in areas with different socioeconomic profile. The modified mall intercept approach was used to target the research participants (Rice and Hancock, 2005). To minimize the time and date effects related bias, the fieldwork was made at different times of the day and different days of the week.

The scales used to measure the constructs of the proposed model were retrieved from different sources to suit the study. The list of all items of the developed measurement instrument and the sources from which they were retrieved are provided in Appendix 1. A seven-point Likert scale ranging from 1 "strongly disagree" to 7 were used to measure all items. The measurement instrument's adequacy and validity were ensured by two focus group of experienced customers respectively. 


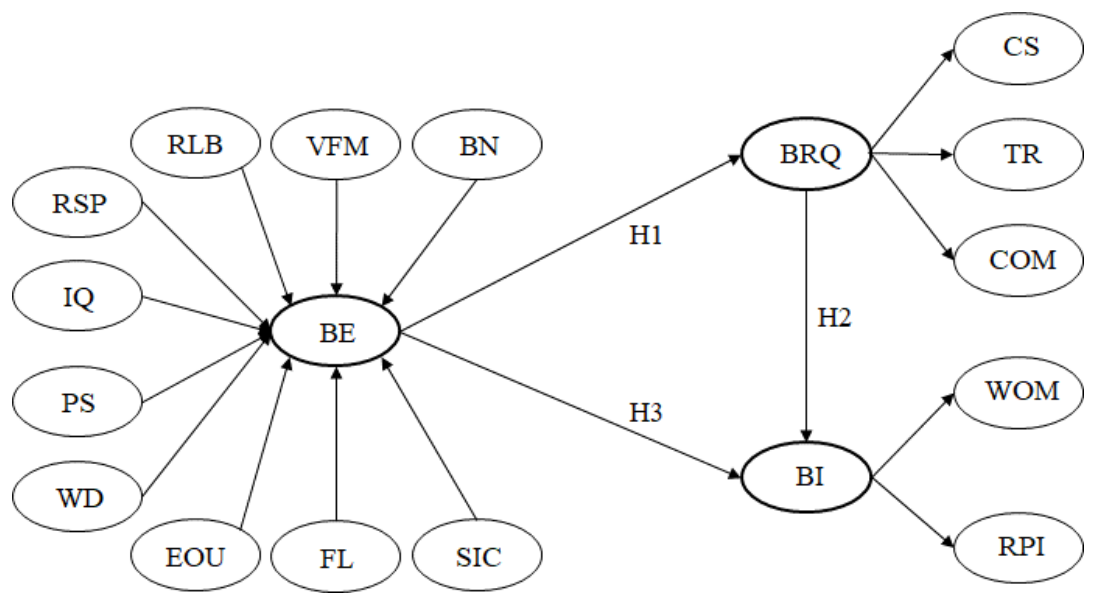

Figure 1. Proposed model

Note: Brand name (BN), Value for money (VFM), Reliability/fulfilment (RLB), Responsiveness (RSP), Information quality/benefits (IQ), Privacy/Security (PS), Web design (WD), Ease-of-use/usability (EOU), Feelings (FL), Self-image congruence (SIC); Brand evidence (BE), Satisfaction (CS), Trust (TR), Commitment (COM), Brand relationship quality (BRQ), Repurchase intentions (RPI), Word-of-mouth (WOM), Behavioural intentions (BI)

The method of partial least squares (PLS) path analysis with Smart PLS 2.o M3 (Ringle et al., 2005), was used to test the proposed hypotheses and examine the predictive ability of the proposed model. Given the complexity of the proposed model, incorporating twenty first-order constructs, one second-order formatively measured construct and two second-order reflectively measured constructs, PLS path analysis is preferred over LISREL-based SEM (Hair et al., 2011).

Table 1. Sample Profile

\begin{tabular}{lll}
\hline Characteristic & Value & \% \\
\hline Gender & Male & 51 \\
Age & Female & 49 \\
& $0-24$ & 32 \\
& $25-34$ & 38 \\
& $35-44$ & 20 \\
Education Background & $45^{+}$ & 10 \\
& Up to High School degree & 37 \\
& University/College degree & 51 \\
Yearly Income & Postgraduate degree & 12 \\
& Less than $€ 10,000$ & 45 \\
& $€ 10,000-€ 19,999$ & 37 \\
& $€ 20,000-49,000$ & 15 \\
Usage Frequency & $50.000+$ & 3 \\
& Less than half times & 15 \\
& $50 \%-79 \%$ of the times & 48 \\
& $80 \%+$ of the times & 37 \\
\hline
\end{tabular}




\section{Results}

Sample profile

Of the 1,00o collected responses, 29 responses with incomplete data were rejected, leaving 971 responses for data analysis. The sample profile in terms of respondent's demographics and service usage is provided in Table 1.

\section{Measurement model assessment}

Based on the PLS path analysis guidelines, the model will be assessed in a two-stages process including the measurement and the structural model's assessment (Hair et al., 2011). The test of the measurement model involves the estimation of item/construct reliability, convergent validity, and discriminant validity of first-order constructs (Hair et al, 2011). The results of measurement model's assessment are given in Table 2.

Table 2. Measurement model assessment - Reliability and convergence validity

\begin{tabular}{|c|c|c|c|c|c|}
\hline Construct & Item & Loading & $\begin{array}{l}\text { Cronbach's } \\
\text { alpha }\end{array}$ & $\begin{array}{l}\text { Composite } \\
\text { Reliability }\end{array}$ & $\begin{array}{l}\text { Avg. Variance } \\
\text { Extracted }\end{array}$ \\
\hline \multirow[t]{4}{*}{ Brand Name } & $\mathrm{BN}_{1}$ & 0.83 & \multirow[t]{4}{*}{0.91} & \multirow[t]{4}{*}{0.94} & \multirow[t]{4}{*}{0.79} \\
\hline & $\mathrm{BN}_{2}$ & 0.91 & & & \\
\hline & $\mathrm{BN}_{3}$ & 0.92 & & & \\
\hline & $\mathrm{BN}_{4}$ & 0.91 & & & \\
\hline \multirow[t]{3}{*}{ Value for Money } & VFM1 & 0.93 & \multirow[t]{3}{*}{0.90} & \multirow[t]{3}{*}{0.94} & \multirow[t]{3}{*}{0.83} \\
\hline & VFM2 & 0.93 & & & \\
\hline & $\mathrm{VFM}_{3}$ & 0.87 & & & \\
\hline \multirow[t]{4}{*}{ Reliability } & RLB1 & 0.79 & \multirow[t]{4}{*}{0.89} & \multirow[t]{4}{*}{0.92} & \multirow[t]{4}{*}{0.75} \\
\hline & $\mathrm{RLB} 2$ & 0.90 & & & \\
\hline & $\mathrm{RLB}_{3}$ & 0.89 & & & \\
\hline & $\mathrm{RLB}_{4}$ & 0.87 & & & \\
\hline \multirow[t]{4}{*}{ Responsiveness } & $\mathrm{RSP} 1$ & 0.86 & \multirow[t]{4}{*}{0.87} & \multirow[t]{4}{*}{0.91} & \multirow[t]{4}{*}{0.73} \\
\hline & $\mathrm{RSP}_{2}$ & 0.86 & & & \\
\hline & $\mathrm{RSP}_{3}$ & 0.88 & & & \\
\hline & $\mathrm{RSP}_{4}$ & 0.81 & & & \\
\hline \multirow[t]{3}{*}{ Privacy/Security } & $\mathrm{PS}_{1}$ & 0.92 & \multirow[t]{3}{*}{0.89} & \multirow[t]{3}{*}{0.93} & \multirow[t]{3}{*}{0.82} \\
\hline & $\mathrm{PS}_{2}$ & 0.93 & & & \\
\hline & $\mathrm{PS}_{3}$ & 0.86 & & & \\
\hline \multirow[t]{4}{*}{ Web Design } & WD1 & 0.83 & \multirow[t]{4}{*}{0.90} & \multirow[t]{4}{*}{0.93} & \multirow[t]{4}{*}{0.78} \\
\hline & $\mathrm{WD}_{2}$ & 0.90 & & & \\
\hline & $\mathrm{WD}_{3}$ & 0.90 & & & \\
\hline & $\mathrm{WD}_{4}$ & 0.89 & & & \\
\hline \multirow[t]{3}{*}{ Ease-of-Use } & EOU1 & 0.89 & \multirow[t]{3}{*}{0.86} & \multirow[t]{3}{*}{0.92} & \multirow[t]{3}{*}{0.86} \\
\hline & $\mathrm{EOU}_{2}$ & 0.90 & & & \\
\hline & $\mathrm{EOU}_{3}$ & 0.86 & & & \\
\hline \multirow{4}{*}{$\begin{array}{l}\text { Information } \\
\text { Quality }\end{array}$} & IQ1 & 0.83 & \multirow[t]{4}{*}{0.90} & 0.93 & 0.78 \\
\hline & $\mathrm{IQ}_{2}$ & 0.91 & & & \\
\hline & $\mathrm{IQ}_{3}$ & 0.89 & & & \\
\hline & $\mathrm{IQ}_{4}$ & 0.89 & & & \\
\hline Feelings & FL1 & 0.92 & 0.95 & 0.95 & 0.63 \\
\hline & FL2 & 0.93 & & & \\
\hline
\end{tabular}




\begin{tabular}{|c|c|c|c|c|c|}
\hline Construct & Item & Loading & $\begin{array}{l}\text { Cronbach's } \\
\text { alpha }\end{array}$ & $\begin{array}{l}\text { Composite } \\
\text { Reliability }\end{array}$ & $\begin{array}{l}\text { Avg. Variance } \\
\text { Extracted }\end{array}$ \\
\hline & FL3 & 0.87 & & & \\
\hline & $\mathrm{FL}_{4}$ & 0.82 & & & \\
\hline & FL5 & 0.80 & & & \\
\hline & FL6 & 0.76 & & & \\
\hline & $\mathrm{FL}_{7}$ & 0.77 & & & \\
\hline & FL8 & 0.79 & & & \\
\hline & FL9 & 0.74 & & & \\
\hline & FLio & 0.71 & & & \\
\hline & FL11 & 0.71 & & & \\
\hline & FL12 & 0.66 & & & \\
\hline Self-image & SIC1 & 0.81 & 0.83 & 0.89 & 0.66 \\
\hline \multirow[t]{3}{*}{ Congruence } & $\mathrm{SIC}_{2}$ & 0.85 & & & \\
\hline & $\mathrm{SIC}_{3}$ & 0.85 & & & \\
\hline & $\mathrm{SIC}_{4}$ & 0.73 & & & \\
\hline Customer & $\mathrm{CS} 1$ & 0.93 & 0.89 & 0.93 & 0.82 \\
\hline \multirow[t]{2}{*}{ Satisfaction } & $\mathrm{CS}_{2}$ & 0.93 & & & \\
\hline & $\mathrm{CS}_{3}$ & 0.85 & & & \\
\hline \multirow[t]{5}{*}{ Trust } & TR1 & 0.86 & 0.93 & 0.95 & 0.79 \\
\hline & TR2 & 0.91 & & & \\
\hline & $\mathrm{TR}_{3}$ & 0.91 & & & \\
\hline & $\mathrm{TR}_{4}$ & 0.89 & & & \\
\hline & $\mathrm{TR}_{5}$ & 0.87 & & & \\
\hline \multirow[t]{4}{*}{ Commitment } & COMı & 0.84 & 0.90 & 0.93 & 0.78 \\
\hline & $\mathrm{COM}_{2}$ & 0.90 & & & \\
\hline & $\mathrm{COM}_{3}$ & 0.91 & & & \\
\hline & $\mathrm{COM}_{4}$ & 0.87 & & & \\
\hline \multirow{3}{*}{$\begin{array}{l}\text { Repurchase } \\
\text { intentions }\end{array}$} & RPI1 & 0.84 & 0.78 & 0.87 & 0.69 \\
\hline & $\mathrm{RPI} 2$ & 0.82 & & & \\
\hline & $\mathrm{RPI}_{3}$ & 0.84 & & & \\
\hline \multirow[t]{3}{*}{ Word-of-mouth } & WOMı & 0.94 & 0.92 & 0.95 & 0.86 \\
\hline & WOM2 & 0.95 & & & \\
\hline & $\mathrm{WOM}_{3}$ & 0.90 & & & \\
\hline
\end{tabular}

To assess individual item reliability, the loadings of each measure with their respective factor were examined. Previous studies suggest the acceptance of items with loadings of 0.7 or more (Hair et al., 2011). As shown in Table 2, all items, in this study, have loadings greater or equal to 0.71 , except one feelings-related item which is 0.66 . This implies that less than half of all item's variances are due to error. This result confirms that all items present satisfactory level of individual item reliability.

The Cronbach's Alpha (CA) and Composite Reliability (CR) measures were used to examine the constructs' reliability. Hair et al. (2011) suggest that the items used to measure a construct are internally consistent when CA and CR value exceeds the threshold of 0.7. As Table 2 shows, the values of CA and $\mathrm{CR}$ for all constructs of the model exceed or are equal to 0.78 and 0.87 respectively. These results suggest adequate construct reliability. The average variance extracted (AVE) was used to assess convergent validity. The AVE value for all constructs was greater or equal to 0.63 , indicating convergent validity, 
since all AVE values exceed the recommended threshold of o.5 (Hair et al., 2011). The Fornell-Larcker criterion was used to assess model's discriminant validity (Hair et al., 2011). The findings support the model's discriminant validity because, the square roots of AVE for all first-order constructs, as shown in Table 3, are higher than their correlations with the other first-order constructs.

The two-stage approach is used to estimate the parameters of the second-order constructs (Wetzels et al., 2009). Brand relationship quality and behavioural intentions are modelled as second-order reflective constructs. To assess the reliability of higher-order reflectively measured constructs, Composite Reliability (CR) and Average Variance Extracted (AVE) indices are used (Wetzels et al., 2009). As it is demonstrated in Table 4, CR and AVE values higher than 0.7 and 0.5 respectively were recorded, both for brand relationship quality $(\mathrm{CR}=0.93$; $\mathrm{AVE}=0.69)$ and behavioural intentions $(\mathrm{CR}=0.93$; $\mathrm{AVE}=$ o.69). Moreover, all loadings of the two second-order constructs on their first-order constructs exceed 0.79 for brand relationship quality and 0.93 for behavioural intentions. These findings provide evidence that both investigated reflectively-measured constructs are reliable (Wetzels et al., 2009).

Table 4. Second-order reflective constructs assessment

\begin{tabular}{llll}
\hline \multicolumn{2}{l}{ Brand Relationship Quality } & \multicolumn{3}{l}{ Behavioural Intentions } \\
\multicolumn{2}{l}{ Composite Reliability: 0.94 } & \multicolumn{2}{l}{ Composite Reliability: 0.93 } \\
Avg. Variance Extracted: 0.59 & Avg. Variance Extracted: o.69 \\
\hline First-order construct & Loadings & First-order construct & Loadings \\
\hline Satisfaction & 0.83 & Repurchase intentions & 0.93 \\
Trust & 0.93 & Word-of-mouth & 0.95 \\
Commitment & 0.79 & & \\
\hline
\end{tabular}

The measurement quality of brand evidence, a second-order formatively measured construct, was assessed following the guidelines provided by Diamantopoulos and Winklhofer (2001). In the first step, the correlation between all constructs structuring brand evidence were examined.

Based on the relevant entries of Table 3, the absolute average correlation among the brand evidencerelated components is 0.49 . This correlation indicates that brand evidence is better measured as formative second-order construct, since reflectively measured constructs usually present extremely high correlation (> o.8) among the items used to measure it. In the second step, the significance of relationships between the higher-order constructs and its components is examined. As shown in Table 5 , six out of ten first-order brand evidence-related components' coefficients were statistically at $p=0.05$. More specifically, feelings, brand name, self-image congruence, information quality, responsiveness and value for money were significantly related with brand evidence. On the other hand, reliability, privacy/security, web design and ease-of-use/usability were not significant determinants of brand evidence. At the end, the variance inflation factors (VIF) for first-order brand evidence components were calculated to assess multicollinearity. As shown in Table 5, all VIF values were less than 5 suggesting that there is no multicollinearity for brand evidence related components. 


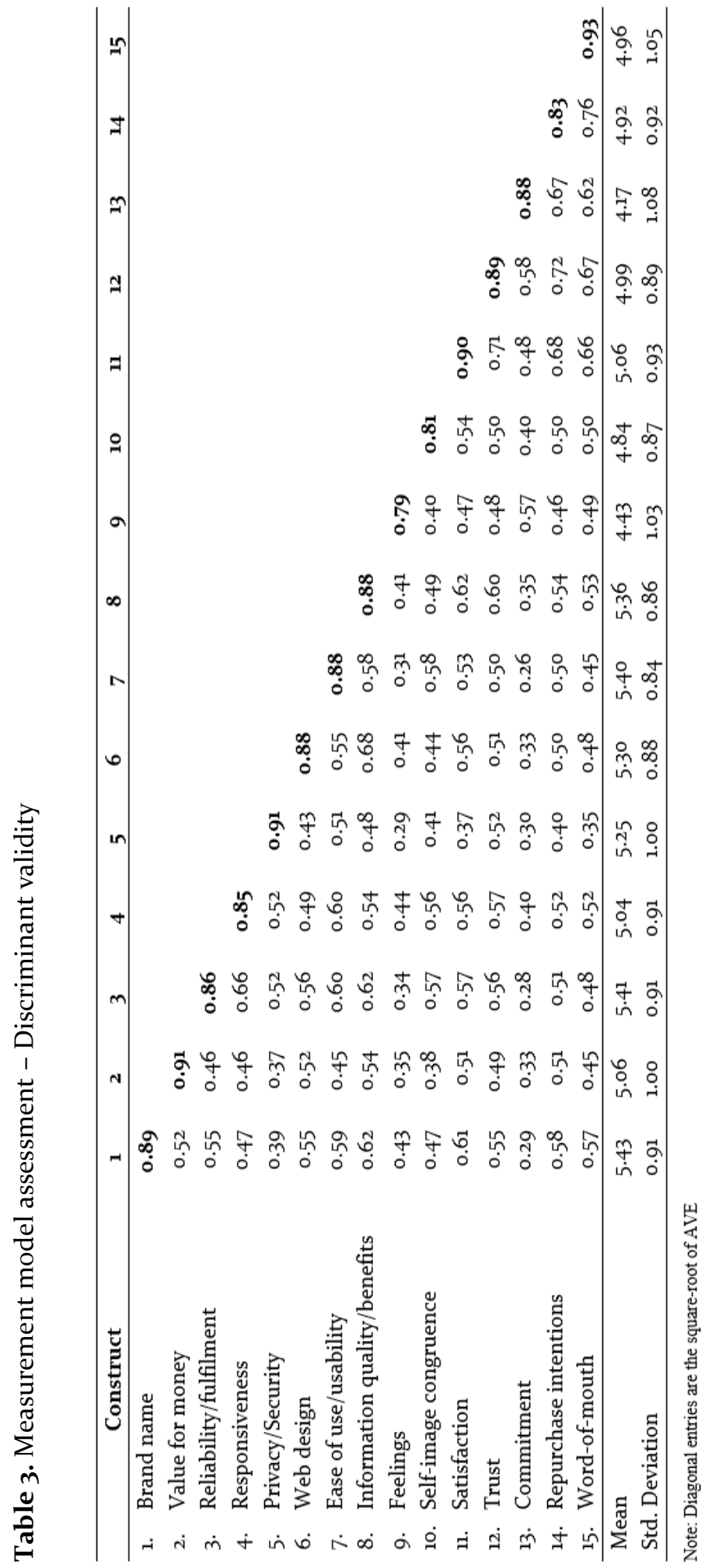


Table 5. Second-order formative construct assessment - Brand evidence

\begin{tabular}{|c|c|c|c|c|c|}
\hline Construct & Weight & t-value & $\begin{array}{l}\text { Lower bound } \\
(95 \%)\end{array}$ & $\begin{array}{l}\text { Upper bound } \\
(95 \%)\end{array}$ & VIF \\
\hline Brand name & $0.24^{* *}$ & 4.05 & 0.13 & 0.35 & 2.31 \\
\hline Value for money & $0.15^{*}$ & 2.85 & 0.05 & 0.25 & 1.84 \\
\hline Reliability/fulfilment & $0.04^{\text {ns }}$ & 0.46 & -0.12 & 0.22 & 2.55 \\
\hline Responsiveness & $0.20^{* *}$ & 2.72 & 0.06 & 0.35 & 2.41 \\
\hline Privacy/Security & $0.07^{\text {ns }}$ & 1.54 & -0.02 & 0.16 & 1.68 \\
\hline Web design & $0.06^{\mathrm{ns}}$ & 1.11 & -0.06 & 0.18 & 2.25 \\
\hline Ease of use/usability & $-0.06^{\mathrm{ns}}$ & -0.74 & -0.23 & 0.10 & 2.77 \\
\hline Information quality/benefits & $0.17^{*}$ & 2.52 & 0.03 & 0.29 & 2.44 \\
\hline Feelings & $0.29^{* *}$ & 7.22 & 0.20 & 0.37 & 1.70 \\
\hline Self-image congruence & $0.20^{* *}$ & 4.24 & 0.11 & 0.30 & 2.06 \\
\hline
\end{tabular}

Note: ${ }^{* *} p<0.01 ;{ }^{*} p<0.05$; not significant (ns)

\section{Structural model assessment}

The PLS path analysis was also employed to assess the validity of the hypotheses representing the relationships between the structural model's constructs. Bootstrapping with 2,00o re-samples was used to calculate the path significance (Hair et al., 2011). To assess the predictive power of the structural model the coefficient of determination $\left(\mathrm{R}^{2}\right)$ for each endogenous latent variable (i.e., brand relationship quality, behavioural intentions) are utilised.

As shown in Table 6, all path coefficients were found to be statistically significant at $5 \%$ level of significance. More specifically, brand evidence strongly influences consumer-brand relationship quality $(\mathrm{b}=0.78 ; \mathrm{t}=38.51)$, explaining $66 \%$ of its variance, and both consumer-brand relationship quality $(\mathrm{b}=$ $0.66 ; t=23.63)$ and brand evidence $(b=0.22 ; t=7.90)$ directly influence behavioural intentions, explaining $70 \%$ of its variance. These results suggest the validity of hypotheses $\mathrm{H}_{1}, \mathrm{H}_{2}$ and $\mathrm{H}_{3}$.

Table 6. Results of the structural model

\begin{tabular}{lllllll}
\hline $\begin{array}{l}\text { Predicted } \\
\text { variable }\end{array}$ & $\begin{array}{l}\text { Predictor } \\
\text { variable }\end{array}$ & Hypothesis & Coefficient & p-value & t-value & $\mathrm{R}^{2}$ \\
\hline BRQ & BE & H1 confirmed & 0.78 & 0.000 & 38.51 & 0.66 \\
BI & BRQ & H2 confirmed & 0.66 & 0.000 & 23.63 & 0.70 \\
& BE & H3 confirmed & 0.22 & 0.000 & 7.90 & \\
\hline
\end{tabular}

Note: Brand Evidence (BE); Brand Relationship Quality (BRQ); Behavioural Intentions (BI)

\section{Mediating effect}

The method proposed by Hayes (2013) was used to test the mediating effect of brand evidence on behavioural intentions carried out by brand relationship quality. The factor scores of these three constructs, obtain in PLS path analysis, was the input dataset for the implementation of the relevant SPSS macro called "Process" (Hayes, 2013). As shown in Table 7 , the value of the investigated indirect effect is 0.51 and is significant at least at $p<0.05$, as its $95 \%$ confidence interval does contain zero (Hayes, 2013). The significance of the mediating effect of brand evidence on behavioural intentions was further validated by inspecting the $\mathrm{z}$-value of the Sobel test. The test $(\mathrm{z}=20.13 ; p<0.001)$ reconfirmed the 
mediation of brand relationship quality on the brand evidence - behavioural intentions link, suggesting the acceptance of $\mathrm{H}_{4}$.

Table 7. Bootstrap results - Indirect and total effects assessment

\begin{tabular}{lllllll}
\hline Path & Effect & Coefficient & Std. error & Sobel z & LB (95\%) & UB (95\%) \\
\hline $\mathrm{BE} \rightarrow \mathrm{BRQ} \rightarrow \mathrm{BI}$ & Indirect & $0.51^{* * *}$ & 0.03 & $20.13^{* * *}$ & 0.45 & 0.58 \\
& Total & $0.73^{* * *}$ & 0.02 & & 0.69 & 0.77 \\
\hline
\end{tabular}

Note: Brand Evidence (BE), Brand Relationship Quality (BRQ), Behavioural Intentions (BI); ${ }^{* * *} p<0.001$

\section{Discussion and implications}

This study enhances our knowledge on how digital brand associations are used by customers to assess their online brand experience with OTA before and during online booking services usage. Theses associations about the brand were examined as drivers of strong consumer-brand relationships and favourable customers' behavioural intentions in terms of repurchase intentions and positive WOM. To achieve this purpose, this paper 1) presented the adaptation of a brand evidence measurement method in the offline context to the online context and 2) proposed and empirically validated a model to interpret the interrelationships among digital brand evidence and brand relationship quality as the former enhances the impact of the latter on consumers' behavioural responses in the context of booking services through OTA websites.

\section{Theoretical implications}

In accordance with previous studies in the offline and online service contexts (i.e., Altunel and Koçak, 2017; Yoon and Youn, 2016), the results indicate that consumers' behavioural responses are not only influenced by OTA's relational-specific actions, but they are also significantly affected by certain brand evidence dimensions, reflecting their transactions-specific actions efficacy. This highlights that online brands' tangible and intangible components jointly strengthen the relational ties with OTA's consumers and further support the achievement of favourable consumer behavioural responses.

More specifically, brand feelings, reflecting consumers' affective brand experience evaluation during and/or after the service delivery stage, were found to be the most important component of OTA's brand evidence, as they significantly determine their experience with this brand use (Kuo and Feng, 2013). Brand name and self-image congruence, which reflect OTA's brand deliverables in the pre-purchase and purchase stage respectively, are the next two most important components of brand evidence. This finding highlights the importance of a well-known OTA's brand that further achieves high congruity between appropriately targeted customers' actual self-concept and its brand image perception in delivering customers' overall favourable brand experiences (Hosany and Martin 2012).

Two OTA's online service quality factors (i.e. responsiveness and information quality) were also found to enhance customers' brand experience (Chang et al., 2019; Huang et al., 2020) and they are anticipated to help OTA in achieving better acquisition and retention rates through the development of highquality relationships with their customers (Chang et al., 2019). All other e-service quality factors were found non-significant, suggesting that customers perceptions about OTAs' brand is not determined by their capabilities to fulfil their task in a reliable way that respect customer's privacy, as well by their digital servicescape design, reflecting its platforms interfaces' easiness and aesthetics. These insignificant effects can be attributed to the standardised nature of booking services, where customers' perceptions about online booking platforms security and privacy protection, easiness and aesthetic might exceed their expectations. 
Finally, consumers' perception about OTA services' price/value for money, although, contributes significantly to the overall brand experience in the pre-purchase stage, it has the lower impact on it. This finding is in accordance with those of other studies suggesting that price is not the dominant driver of OTA's brand choice (Bilgihan et al., 2016; Ye et al., 2020).

\section{Practical implications}

The findings of this study provide useful insights pertaining to the management of brand transactionand brand relational-specific experiences, used by customers to assess OTA's performance, in order to decide whether to remain loyal or switch service providers, as well as to proceed or not with positive suggestions about the brand to their surrounding. OTA have to invest in delivering better brand experiences before and during the customers' transaction stages in order to improve their customers' repurchasing rates, as well their acquisition rate, through the positive word-of-mouth effect. As such, in the pre-transaction stage, they have to focus on promoting brand reputation and familiarity to reduce perceived risk and enhance brand trust. They also need to safeguard that prices are perceived by consumers as being logical. In the transaction stage, they have to ensure user's self-image congruence by developing a brand personality similar to that of their current and potential buyers and, further, provide the appropriate benefits and, ultimately, create positive feelings during a service encounter.

\section{Limitations and directions for future research}

This study, despite its significance, has certain limitations, which can also be seen as directions for future research. The current study investigates only the effect of brand evidence on brand relationship quality and consumers' behavioural intentions and not that of brand controlled and non-controlled brand-related communication (i.e., advertising, sales promotion, and publicity) experienced by consumers (Grace and O'Cass, 2005). Future studies can incorporate brand-related communication into the proposed model to investigate the combined effects of both service brand dimensions on consumers' responses. The proposed model could be further extended in the future by considering the moderating effects of individuals' characteristics such as brand's familiarity and involvement (Krystallis and Chrysochou, 2014) and length of the consumer-brand relationship (Nyffenegger et al., 2014) to better reflect consumer's decision making and behaviour.

\section{References}

Aaker, D. A. (1996). Building Strong Brands. New York: The Free Press.

Aaker, J., Fournier, S. \& Brasel, S.A. (2004). When good brands do bad. Journal of Consumer Research, 31(1), 1-16.

Altunel, M. C., \& Koçak, Ö. E. (2017). The roles of subjective vitality, involvement, experience quality, and satisfaction in tourists' behavioral intentions. European Journal of Tourism Research, 16(1), 233.

Babin, B. J., \& Babin, L. (2001). Seeking something different? A model of schema typicality, consumer affect, purchase intentions and perceived shopping value. Journal of Business Research, 54(2), 89-96.

Barnes, S.J., \& Vidgen, R.T. (2002). An integrative approach to the assessment of e-commerce quality. Journal of Electronic Commerce Research, 3(3), 114-127.

Bauer, H. H., Falk, T., \& Hammerschmidt, M. (2006). eTransQual: a transaction process-based approach for capturing service quality in online shopping. Journal of Business Research, 59(7), 866-875.

Bilgihan, A. (2016). Gen Y customer loyalty in online shopping: an integrated model of trust, user experience and branding. Computers in Human Behavior, 61(1), 103-113.

Bilgihan, A., \& Bujisic, M. (2015). The effect of website features in online relationship marketing: A case of online hotel booking. Electronic Commerce Research and Applications, 14(4), 222-232. 
Bilgihan, A., Kandampully, J. A., \& Zhang, T. C. (2016). Towards a unified customer experience in online shopping environments: Antecedents and outcomes. International Journal of Quality and Service Sciences, 8(1), 102-119.

Brady, M. K., \& Cronin Jr, J. J. (2001). Some new thoughts on conceptualizing perceived service quality: a hierarchical approach. Journal of Marketing, 65(3), 34-49.

Brady, M. K., Knight, G. A., Cronin Jr, J. J., Tomas, G., Hult, M., \& Keillor, B. D. (2005). Removing the contextual lens: A multinational, multi-setting comparison of service evaluation models. Journal of Retailing, 81(3), 215-230.

Brun, I., Rajaobelina, L., \& Ricard, L. (2014). Online relationship quality: scale development and initial testing. International Journal of Bank Marketing, 32(1), 5-27.

Buhalis, D., \& Law, R. (2008). Progress in information technology and tourism management: 20 years on and 10 years after the Internet - the state of eTourism research. Tourism Management, 29(1), 6o9623.

Buhalis, D., \& Sinarta, Y. (2019). Real-time co-creation and nowness service: lessons from tourism and hospitality. Journal of Travel \& Tourism Marketing, 36(5), 563-582.

Carlson, J., \& O'Cass, A. (2011). Developing a framework for understanding e-service quality, its antecedents, consequences, and mediators. Managing Service Quality: An International Journal, 21(3), 264-286.

Chang, Y. W., Hsu, P. Y., \& Lan, Y. C. (2019). Cooperation and competition between online travel agencies and hotels. Tourism Management, 71(1), 187-196.

Chaudhuri, A., \& Holbrook, M.B. (2001). The chain of effects from brand trust and brand affect to brand performance: The role of brand loyalty", Journal of Marketing, 65(1), 81-93.

Chiu, C. M., Cheng, H. L., Huang, H. Y., \& Chen, C. F. (2013). Exploring individuals' subjective wellbeing and loyalty towards social network sites from the perspective of network externalities: the Facebook case. International Journal of Information Management, 33(3), 539-552.

Collier, J.E., \& Bienstock, C.C. (2006). Measuring service quality in e-retailing. Journal of Service Research, 8(3), 260-275.

Cristobal, E., Flavián, C., \& Guinaliu, M. (2007). Perceived e-service quality PeSQ: measurement validation and effects on consumer satisfaction and web site loyalty. Managing Service Quality, 17(3), 317-340.

De Chernatony, L., \& Riley, F. D. O. (1997). The chasm between managers' and consumers' views of brands: the experts' perspectives. Journal of Strategic Marketing, 5(2), 89-104.

Degeratu, A. M., Rangaswamy, A., \& Wu, J. (2000). Consumer choice behavior in online and traditional supermarkets: The effects of brand name, price, and other search attributes. International Journal of Research in Marketing, 17(1), 55-78.

Diamantopoulos, A., \& Winklhofer, H. (2001). Index construction with formative indicators: an alternative to scale development. Journal of Marketing Research, 38(2), 269-277.

Fournier, S. (1998). Consumers and their brands: Developing relationship theory in consumer research. Journal of Consumer Research, 24(4), 343-373.

Giovanis, A. N., \& Athanasopoulou, P. (2014). Gaining customer loyalty in the e-tailing marketplace: the role of e-service quality, e-satisfaction and e-trust. International Journal of Technology Marketing, 9(3), 288-304.

Giovanis, A. N., \& Melanthiou, Y. (2017). Retailer loyalty in the online context: The influence of transactional and relational experiences assessment. Journal of Customer Behaviour, 16(1), 35-59.

Grace, D., \& O'Cass, A. (2005). Service branding: consumer verdicts on service brands. Journal of Retailing and Consumer Services, 12 (2), 125-139.

Hair, J. F., Ringle, C. M., \& Sarstedt, M. (2011). PLS-SEM: Indeed a silver bullet. Journal of Marketing theory and Practice, 19(2), 139-152. 
Hayes, A.F. (2013), Introduction to Mediation, Moderation, and Conditional Process Analysis: A Regression-Based Approach, New York: Guilford Press.

Hellier, P. K., Geursen, G. M., Carr, R. A., \& Rickard, J. A. (2003). Customer repurchase intention: a general structural equation model. European Journal of Marketing, 37(11/12), 1762-18oo.

Hosany, S., \& Martin, D. (2012). Self-image congruence in consumer behavior. Journal of Business Research, 65(5), 685-691.

Huang, C. C., Chang, Y. W., Hsu, P. Y., \& Prassida, G. F. (2020). A cross-country investigation of customer transactions from online to offline channels. Industrial Management E Data Systems, 120(12), 2397-2422.

Keating, B. W., Alpert, F., Kriz, A., \& Quazi, A. (2011). Mediating role of relationship quality in online services. Journal of Computer Information Systems, 52(2), 33-41.

Keller, K.L. (1993). Conceptualizing, measuring, and managing customer-based brand equity. Journal of Marketing, 57(1), pp. 1-22.

Kim, J., Jin, B., \& Swinney, J. L. (2009). The role of etail quality, e-satisfaction and e-trust in online loyalty development process. Journal of Retailing and Consumer Services, 16(4), 239-247.

Kotler, P., \& Armstrong, G. (2010). Principles of Marketing. NJ: Pearson education.

Kuo, Y. F., Wu, C. M., \& Deng, W. J. (2009). The relationships among service quality, perceived value, customer satisfaction, and post-purchase intention in mobile value-added services. Computers in Human Behavior, 25(4), 887-896.

Kuo, Y. F., \& Feng, L. H. (2013). Relationships among community interaction characteristics, perceived benefits, community commitment, and oppositional brand loyalty in online brand communities. International Journal of Information Management, 33(6), 948-962.

Ladhari, R. (2010). Developing e-service quality scales: a literature review. Journal of Retailing and Consumer Services, $17(6)$, 464-477.

Ladhari, R., \& Leclerc, A. (2013). Building loyalty with online financial services customers: Is there a gender difference? Journal of Retailing and Consumer Services, 2o(6), 560-569.

Lin, C. H., Sher, P. J., \& Shih, H. Y. (2005). Past progress and future directions in conceptualizing customer perceived value. International Journal of Service Industry Management, 16(4), 318-336.

Lin, H. H., \& Wang, Y. S. (2006). An examination of the determinants of customer loyalty in mobile commerce contexts. Information \& Management, 43(3), 271-282.

Loiacono, E.T., Watson, R.T., \& Goodhue, D.L. (2007). WebQual: an instrument for consumer evaluation of web sites. International Journal of Electronic Commerce, 11(3), 51-87.

Loureiro, M. C. S., Miranda, F., \& Breazeale, M. (2014). Who needs delight? The greater impact of value, trust and satisfaction in utilitarian, frequent-use retail. Journal of Service Management, 25(1), 101-124.

Martin-Fuentes, E. \& Mellinas, J. (2018). Hotels that most rely on booking.com - online travel agencies (OTAs) and hotel distribution channels. Tourism Review, 73(4), 465-479.

Morgan, R. M., \& Hunt, S. D. (1994). The commitment-trust theory of relationship marketing. Journal of Marketing, 58(3), 20-38.

Mouakket, S., \& Al-hawari, M. A. (2012). Examining the antecedents of e-loyalty intention in an online reservation environment. The Journal of High Technology Management Research, 23(1), 46-57.

Nam, J., Ekinci, Y., \& Whyatt, G. (2011). Brand equity, brand loyalty and consumer satisfaction. Annals of Tourism Research, 38(3), 1009-1030.

Navío-Marco, J., Ruiz-Gómez, L. M., \& Sevilla-Sevilla, C. (2018). Progress in information technology and tourism management: 30 years on and 20 years after the internet-revisiting Buhalis \& Law's landmark study about eTourism. Tourism Management, 69(1), 460-470.

Nyffenegger, B., Krohmer, H., Hoyer, W. D., \& Malaer, L. (2015). Service brand relationship quality: hot or cold? Journal of Service Research, 18(1), 90-106. 
O'Cass, A., \& Grace, D. (2004). Exploring consumer experiences with a service brand. Journal of Product $\mathcal{E}$ Brand Management, 13(4), 257-268.

O'Cass, A., \& Lim, K. (2002). The influence of brand associations on brand preference and purchase intention: An Asian perspective on brand associations. Journal of International Consumer Marketing, 14(2-3), 41-71.

Oliver, R.L. (1999). Whence consumer loyalty? Journal of Marketing, 63(1), 33-44.

Ozturk, A. B., Nusair, K., Okumus, F., \& Hua, N. (2016). The role of utilitarian and hedonic values on users' continued usage intention in a mobile hotel booking environment. International Journal of Hospitality Management, 57(1), 106-115.

Papista, E., \& Dimitriadis, S. (2012). Exploring consumer-brand relationship quality and identification: qualitative evidence from cosmetics brands. Qualitative Market Research: An International Journal, 15(1), 33-56.

Parasuraman, A., Zeithaml, V.A., \& Malhotra, A. (2005). ES-QUAL a multiple-item scale for assessing electronic service quality. Journal of Service Research, 7(3), 213-233.

Ribbink, D., van Riel, A.C.R., Liljander, V., \& Streukens, S. (2004). Comfort your online customer: quality, trust and loyalty on the internet. Managing Service Quality, 14(6), 446- 456.

Ramírez, S.A.O., Veloutsou, V. \& Morgan-Thomas, A. (2017). A systematic literature review of brand commitment: definitions, perspectives and dimensions. Athens Journal of Business $\mathcal{E}$ Economics, 3(3), 305-332.

Rezgo, (2019). Tour \& activity industry terms. URL: https://www.rezgo.com/glossary/ota (Accessed on 25.10.2020).

Rice, R., \& Hancock, L. (2005). The mall intercept: a social norms marketing research tool. 7The Report on Social Norms, 4(7), 4-7.

Ringle C.M., Wende, S. and Will, A. (2005). SmartPLS 2.0 (M3) Beta. Hamburg. URL: available at http://wwwsmartpls.de (Accessed on 05.05.2010).

Rolland, S., \& Freeman, I. (2010). A new measure of e-service quality in France. International Journal of Retail \& Distribution Management, 38(7), 497-517.

Rowles, D. (2014). Digital branding: a complete step-by-step guide to strategy, tactics and measurement. London, UK: Kogan Page Publishers.

Rowley, J. (2009). Online branding strategies of UK fashion retailers. Internet Research, 19(3), 348-369.

Sharma, A., Sharma, S. \& Chaudhary, M. (2020). Are small travel agencies ready for digital marketing? Views of travel agency managers. Tourism Management, 79, 1-10.

Sirgy, M. J., Grewal, D., Mangleburg, T. F., Park, J. O., Chon, K. S., Claiborne, C. B., ... \& Berkman, H. (1997). Assessing the predictive validity of two methods of measuring self-image congruence. Journal of the Academy of Marketing Science, 25(3), 229.

Sop, S. A., \& Kozak, N. (2019). Effects of brand personality, self-congruity and functional congruity on hotel brand loyalty. Journal of Hospitality Marketing E Management, 28(8), 926-956.

Sop, S. (2020). Self-congruity theory in tourism research: A systematic review and future research directions. European Journal of Tourism Research, 26, 2604-2604.

Sreejesh, S. \& Roy, S. (2015). A new consumer-brand relationship framework. In M. Fetscherin \& T. Heilmann (eds.), Consumer Brand Relationships, NY: Palgrave-Macmillan, 165-197

Sun, H. (2010). Transferring attributes of e-commerce systems into business benefits: a relationship quality perspective. Journal of Electronic Commerce Research, 11(2), 92-109.

Talwar, S., Dhir, A., Kaur, P., \& Mäntymäki, M. (2020). Why do people purchase from online travel agencies (OTAs)? A consumption values perspective. International Journal of Hospitality Management, 88(1), 102534. 
Toufaily, E., Ricard, L., \& Perrien, J. (2013). Customer loyalty to a commercial website: descriptive metaanalysis of the empirical literature and proposal of an integrative model. Journal of Business Research, 66(9), 1436-1447.

Tsai, S. P. (2011). Fostering international brand loyalty through committed and attached relationships. International Business Review, 20(5), 521-534.

Veloutsou, C. (2015). Brand evaluation, satisfaction and trust as predictors of brand loyalty: the mediator-moderator effect of brand relationships. Journal of Consumer Marketing, 32(6), 405-421.

Verhoef, P. C., Franses, P. H., \& Hoekstra, J. C. (2002). The effect of relational constructs on customer referrals and number of services purchased from a multiservice provider: does age of relationship matter? Journal of the Academy of Marketing Science, 30(3), 202-216.

Wang, S., Hung, K., Li, M., \& Qiu, H. (2020). Developing a customer loyalty model for guest houses in China: a congruity-based perspective. Tourism Review, 76(2), 411-426.

Wassler, P., Wang, L., \& Hung, K. (2019). Identity and destination branding among residents: How does brand self-congruity influence brand attitude and ambassadorial behavior? International Journal of Tourism Research, 21(4), 437-446.

Webb, H.W., \& Webb, L.A. (2004). SiteQual: an integrated measure of web site quality. The Journal of Enterprise Information Management, 17(6), 430-440.

Westbrook, R. A. (1987). Product/consumption-based affective responses and post purchase processes. Journal of Marketing Research, 24(3), 258-270.

Wetzels, M., Odekerken-Schröder, G., \& Van Oppen, C. (2009). Using PLS path modeling for assessing hierarchical construct models: Guidelines and empirical illustration. MIS Quarterly, 33(1), 177-195.

Wolfinbarger, M., \& Gilly, M.C. (2003). eTailQ: dimensionalizing, measuring and predicting etail quality. Journal of Retailing, 79(3), 183-198.

Xiang, Z., Magnini, V. P., \& Fesenmaier, D. R. (2015). Information technology and consumer behavior in travel and tourism: insights from travel planning using the internet. Journal of Retailing and Consumer Services, 22(1), 244-249.

$\mathrm{Xu}, \mathrm{X}$., \& Pratt, S. (2018). Social media influencers as endorsers to promote travel destinations: An application of self-congruence theory to the Chinese generation Y. Journal of Travel $\mathcal{E}$ Tourism Marketing, 35(7), 958-97.

Yang, Z., Cai, S., Zhou, Z., \& Zhou, N. (2005). Development and validation of an instrument to measure user perceived service quality of information presenting web portals. Information $\mathcal{E}$ Management, 42(4), 575-589.

Ye, B. H., Barreda, A. A., Okumus, F., \& Nusair, K. (2019). Website interactivity and brand development of online travel agencies in China: The moderating role of age. Journal of Business Research, 99(1), 382-389.

Yoo, B., \& Donthu, N. (2001). Developing a scale to measure the perceived quality of an Internet shopping site SITEQUAL. Quarterly Journal of Electronic Commerce, 2(1), 31-45.

Zeithaml, V. A. (1988). Consumer perceptions of price, quality and value: a means-end model and synthesis of evidence. Journal of Marketing, 52(3), 2-22.

Zeithaml, V. A., Berry, L. L., \& Parasuraman, A. (1996). The behavioral consequences of service quality. Journal of Marketing, 6o(2), 31-46.

Zeithaml, V.A., Parasuraman, A., \& Malhotra, A. (2002). Service quality delivery through web sites: a critical review of extant knowledge. Journal of the Academy of Marketing Science, 30 (4), 362-375.

Zhang, Y., Fang, Y., Wei, K. K., Ramsey, E., McCole, P., \& Chen, H. (2011). Repurchase intention in B2C e-commerce - A relationship quality perspective. Information $\mathcal{E}$ Management, 48(6), 192-20o. 


\section{Appendix 1. Questionnaire's items per construct}

\section{Brand name (Source: Grace and O'Cass, 2005)}

$\mathrm{BN1}$ : The name of this OTA tells me a lot about what to expect from this service provider BN2: The name of this OTA tells me a lot about this service provider

$\mathrm{BN}_{3}$ : The name of this OTA means something to me

BN4: The name of this OTA sends a message to me about this service provider

Price/value for money (Source: Grace and O'Cass, 2005)

VFM1: This OTA's services is reasonably priced

VFM2: This OTA's offers satisfactory value for what it costs

VFM3: This OTA provides a good service for its price

Feelings (Source: Grace and O'Cass, 2005)

FL1: When using this OTA, I feel annoyed (reverse scored)

FL2: When using this OTA, I feel happy

FL3: When using this OTA, I feel irritated (reverse scored)

FL4: When using this OTA, I feel frustrated (reverse scored)

FL5: When using this OTA, I feel pleased

FL6: When using this OTA, I feel sad (reverse scored)

FL7: When using this OTA, I feel disgusted (reverse scored)

FL8: When using this OTA, I feel uneasy (reverse scored)

FL9: When using this OTA, I feel good

FL10: When using this OTA, I feel nervous (reverse scored)

FL11: When using this OTA, I feel confident

FL12: When using this OTA, I feel impressed

Self-image congruence (Source: Grace and O'Cass, 2005)

SIC1: The image of this OTA is consistent with my own self-image

SIC2: Using this OTA reflects who I am

$\mathrm{SIC}_{3}$ : People similar to me use this OTA

SIC4: The kind of person who typically use this OTA is very much like me

Reliability (Source: Webb and Webb, 2004)

RLB1: This OTA provides services as promised

RLB2: This OTA presents dependability in handling customers' service problems

RLB3: This OTA performs services right the first time

RLB4: This OTA provides services at the promised time

Responsiveness (Source: Webb and Webb, 2004)

RSP1: This OTA keeps customers informed about when services will be performed

RSP2: This OTA provides prompt service to customers

$\mathrm{RSP}_{3}$ : This OTA makes it easy to communicate with the organization

RSP4: This OTA is always ready to respond to customers' requests

Privacy/security (Source: Kim et al., 2009)

PS1: I feel safe in my transactions with this OTA

PS2: I trust this OTA to keep my personal information safe

$P_{3}$ : I trust this OTA will not misuse my personal information

Web design (Source: Collier and Bienstock, 2006)

WD1: This OTA's website is visually appealing

WD2: The OTA's website is professional

WD3: The OTA's website is innovative

WD4: The OTA's website content is easy to read 
Ease of use (Source: Yang et al., 2005)

EOU1: Using this OTA's website does not require a lot of effort

EOU2: The organization and structure of content of this OTA's website is easy to follow

EOU3: It is easy for me to complete a transaction through this OTA's website

Information quality (Source: Ladhari and Leclerc, 2013)

IQ1: Information provided on the OTA's website is up to date

IQ2: Information provided on the OTA's website is relevant

IQ3: Information provided on the OTA's website is easy to understand

IQ4: This OTA's website provides all the information necessary

\section{Satisfaction (Source: Carlson and O'Cass, 2011)}

CS1: My choice to use this OTA was a wise one

CS2: Overall, I am satisfied with this OTA

CS3: I think I did the right thing when I decided to this OTA

Trust (Source: Verhoef et al., 2002)

TR1: I trust this OTA

TR2: This OTA has high integrity

TR3: This OTA can be counted on to do what is right

TR4: This OTA cares about me

TR5: If problems arise, OTA is honest about the problems

Commitment (Source: Morgan and Hunt, 1994)

COM1: The relationship that I have with this OTA is very important to me

COM2: What I have with this OTA is something I intend to maintain indefinitely

$\mathrm{COM}_{3}$ : The relationship that I have with this OTA is very much like being a friend

$\mathrm{COM}_{4}$ : The relationship that I have with this OTA is something I really care about

Repurchase Intention (Source: Chiu et al., 2013)

RPI1: If I could, I would like to continue using this OTA in the future.

RPI2: It is likely that I will continue using this OTA in the future.

$\mathrm{RPI}_{3}$ : I plan to continue using this OTA in the future.

Word-of-Mouth (WOM) (Source: Chiu et al., 2013)

WOM1: I would like to introduce this OTA to others.

WOM2: I will speak favourably about this OTA to others.

WOM3: I will tell others the positive aspects about this OTA.

Received: 01/04/2019

Accepted: 19/04/2021

Coordinating editors: Maro Vlachopoulou and Konstantinos Fouskas 